\title{
An Evaluation on the Last Ecdysis in Galeodids (Galeodidae, Solifugae, Arachnida)
}

\author{
Melek ERDEK
}

Hakkâri University, Vocational School of Health Services, Department of Medical Services and Techniques, Hakkâri, Turkey ORCID ID: Melek ERDEK: http:/ / orcid.org/0000-0003-1060-4265

\begin{tabular}{llll}
\hline Received: 31.03 .2021 & Accepted: 17.06 .2021 & Published online: 25.06 .2021 & Issue published: 30.06 .2021 \\
\hline
\end{tabular}

\begin{abstract}
In this study, the observations on pre-ecdysis and post-ecdysis during the last ecdysis of Galeodes sp. were recorded. During the ecdysis, a strand-like structure, intracuticular fibre, occurs between the old cuticle and the new one. This intracuticular fibre consists of the tracheal tubes as well as the old cuticle pieces. Thanks to this structure, the solifuge continues its biological activities such as breathing, even at a minimum level, during the quiescence process of the ecdysis. Forming male cheliceral flagellum during the last ecdysis leads to accurate sex determination.
\end{abstract}

Keywords: Solifuge, moulting, exuvia, trachea.

\section{Galeodidlerde Son Deri Değişimi Üzerine Bir Değerlendirme (Galeodidae, Solifugae, Arachnida)}

\begin{abstract}
Öz: Bu çalışmada Galeodes sp. türüne ait son deri değişimi öncesinde ve sonrasındaki gözlemler kaydedilmiştir. Deri değişimi sırasında eski deri ile yeni deri arasında kütikulalar arası iplik benzeri doku oluşmaktadır. Bu doku kütikula parçalarının yanısıra içerisinde trake borularını da içermektedir. Böğü bu yapı sayesinde deri değişimi sırasındaki durgunluk sürecinde, solunum gibi hayati faaliyetlerini minimum düzeyde de olsa sürdürmektedir. Son deri atımından sonra oluşan bireyin yetişkin erkek ya da dişi olduğu kesinleşmektedir.
\end{abstract}

Anahtar kelimeler: Böğü, deri değiştirme, eksuvia, trake.

\section{Introduction}

The arachnids of the order Solifugae are fast-moving predaceous animals, comprising more than 1100 species belonging to 138 genera and 12 extant families (Harvey, 2003; Erdek, 2019). Many solifuges are predominantly univoltine and active for only short periods of their life cycle, not living for more than one year (Punzo, 1998). Muma (1966) recorded his observations on postembryonal ecdysis of Eremobates durangonus Roewer, 1934. Haupt (1982) questioned that the shedding of cuticle causing problems for the functional permanence of cuticular sense structures during ecdysis and studied the hair regeneration of a chemotactile sensillum in Gluvia dorsalis (Latreille, 1817). Wharton (1981) pointed out that moulting caused a dental modification in Biton (Biton) striatus (Lawrence, 1928). It was previously suggested that the flagellum is formed just before males attain sexual maturity during the last ecdysis (Punzo, 1998).

The purpose of this study was to observe and record the events that occur during the pre-ecdysial and postecdysial development of the last ecdysis in a species of Galeodes and evaluate its exuvial morphology.

\section{Material and Methods}

The pre-ecdysial specimen of Galeodes sp. was collected in southeast Turkey (Hakkari Province, Demirtaş Village, Yağmurlu Hamlet, 3743'58.14" N, 4359'35.22" E, 2229m a.s.1., 29.06.2019) (Fig. 1A-B) and kept under observation in the laboratory (Fig. 1C-F). The species could not be fully identified because of the insufficient number of specimens and also its main characteristics were not fully formed. Specimens were maintained in the laboratory in a glass bell jar (50 cm diameter and $20 \mathrm{~cm}$ height) containing a layer of soil about $4-5 \mathrm{~cm}$ in height at room temperature. A small stone was put to provide a hiding place during the daylight hours and wet cotton wool for providing humidity. For feeding, larvae of Tenebrio molitor Linnaeus, 1758 (Coleoptera) were provided daily. Digital images were taken using a digital camera attached to Leica DFC295 stereomicroscope. For scanning electron microscopy (SEM) analysis, the exuvial junction part was cleaned and air-dried. After gold-coated in a Quorum SC7620 sputter coater, it was studied and photographed at an accelerating voltage of $10 \mathrm{kV}$ in a ZEISS Sigma 300 scanning electron microscope at the Science Application and Research Center in Van Yüzüncü Yil University.

\section{Results}

The preecdysial galeodid was found in a burrow under a stone in the habitat (Fig. 1A-B). The chelicerae, pedipalps, four pairs of legs, and opistosoma of galeodid were bent up dorsally in the 17-day period between the date taken from the habitat to moulting (Fig. 1C-D). The chelicerae and propeltidium were swollen and the ocular tubercle became transparent in 3-4 days (Fig. 1D). The galeodid squirmed its opisthosoma at irregular intervals.

The first exuvial rupture occurred in propeltidial surface behind the ocular tubercle (Fig. 2B-C). There was 

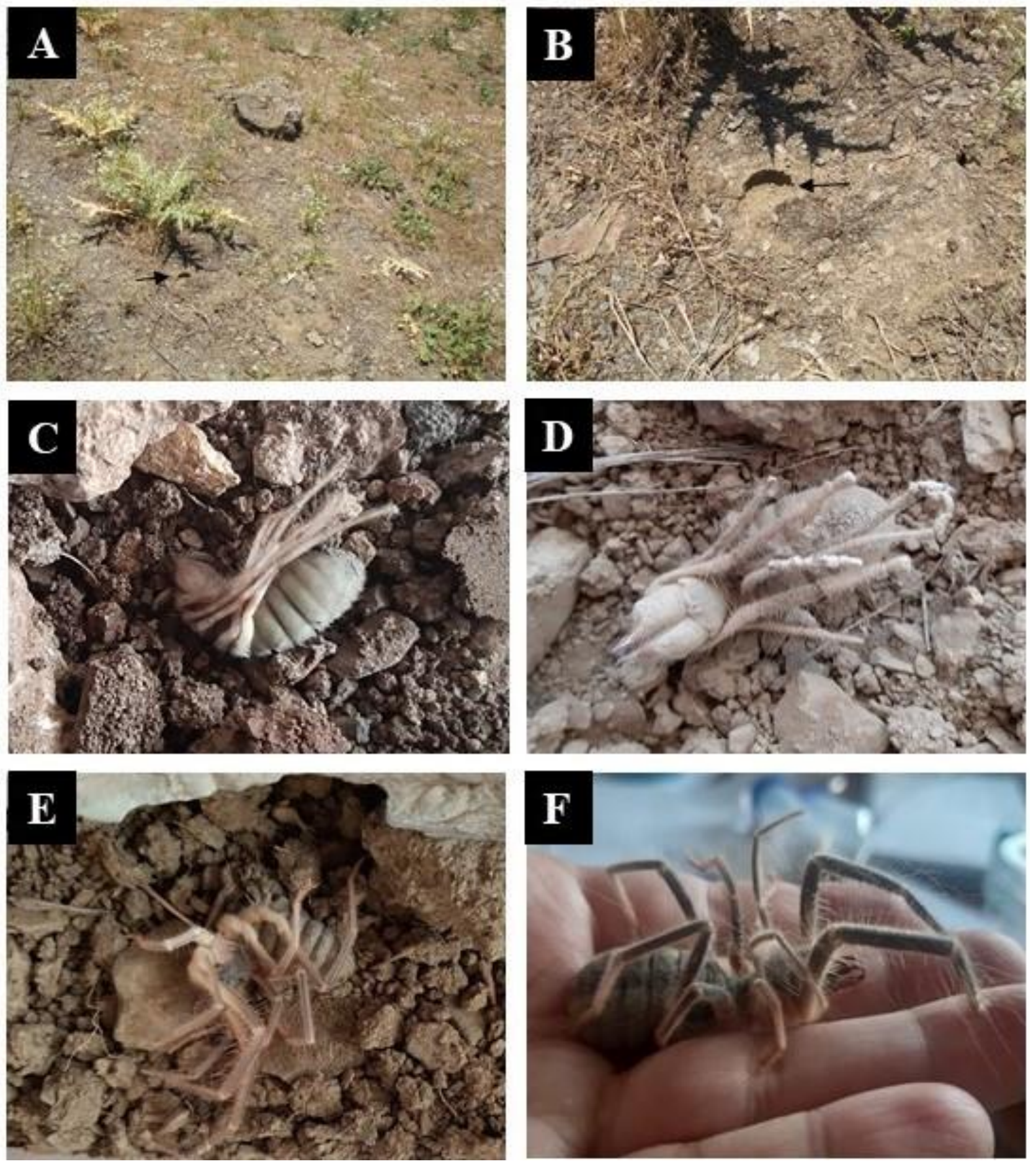

Figure 1. The burrow of Galeodes sp. in habitat (A). Close-up view of the burrow (B). Dormancy position in preecdysial galeodid, laterally (C), dorsally (D). The general overview of galeodid just after ecdysis (E), a few days after ecdysis (F).

an intracuticular fibre, whitish and $2.8 \mathrm{~cm}$ in length, on the propeltidial exuvium behind the transversal rupture (Fig. 2A-C). The muscle-like structure was also observed on coxal junction of pedipalp as well as the intracuticular fibre (Fig. 2D). There are local moulting areas on the ventral surface of pedipalpal coxa, whose socket structures were clearly visible (Fig. 2D, 3D). This intracuticular fibre consists of folded exuvial skin and tube-like tracheae under this exuvial skin (Fig. 3A, C). The tracheal surface is thrown into longitudinal folds equally (Fig. 4A-B) and the surface of tracheae reveals tiny transversal anastomosing folds (Fig. 4B).
The chelicerae tip and the tarsal claws of the legs have not shed their skin and have fallen off as a whole because they are completely renewed. (Fig. 2A-B). Just after ecdysis, the male cheliceral flagellum was visible and the whole body surface seemed glossy, soft, and fragile (Fig. 1E). The chelicerae, pedipalps, four pairs of legs, and opisthosoma of galeodid were bent up dorsally. Within a few days, the surface became dull and sensilla on the body surface became more visible (Fig. 1F). The last ecdysis process was completed in about 16 hours and it received its first food about 68 hours after ecdysis. In this process, the galeodid did not move actively on the ground, just only small twitches occurred in its place (Fig. 1E). 

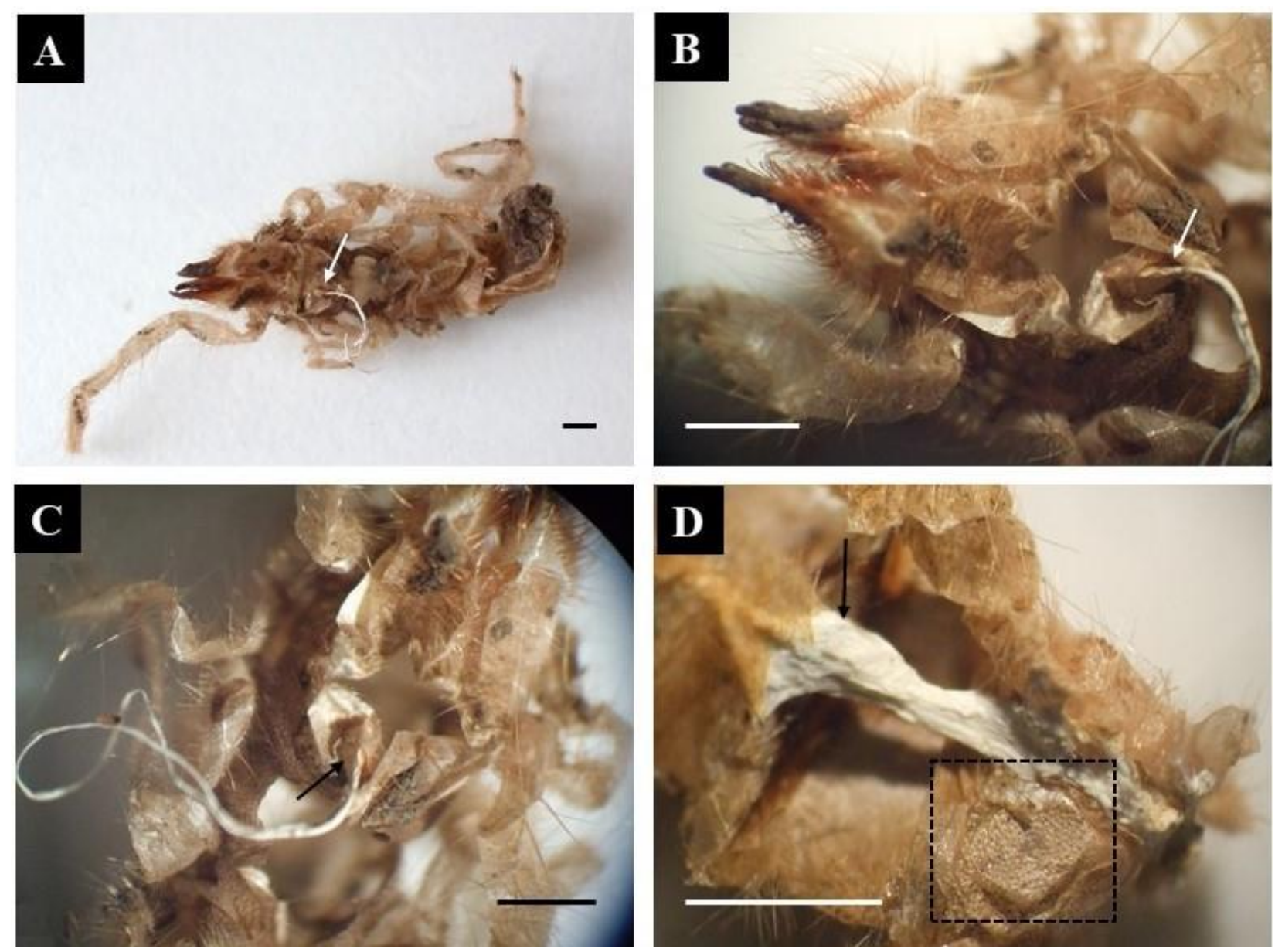

Figure 2. The exuviae of Galeodes sp., dorsally (A-D), Exuvial sheath of whole body (A), Exuvial sheath of chelicerae and propeltidium (BC). ventral surface of pedipalpal coxa (D). (Arrow show intracuticular fibre (C) and muscle-like structure (D), square shows setal moulted area of pedipalpal coxa) (Scale bars: $2 \mathrm{~mm}$ ).

\section{Discussion}

The behaviors and events before and after moulting during the last ecdysis were observed and reported in the present study. The reason it is called "the last ecdysis" because the male flagellum is formed at the end of this ecdysis process. Partial moulting was observed especially for proximal segments of extremities. This moulting was like breakages of sensilla. Most of the sensilla on the body surface especially on chelicerae were not moulted. The moult cycle culminates in ecdysis. Haupt (1982) indicated that the old sensilla in the old cuticle remain connected to the epidermis during apolysis by dendrites, though the exuvial space widening. In this study, it was observed that the intracuticular fibre consists of exuvial sheath and tracheal trunks. Until the solifuge comes out of the exuvial sheath, this intracuticular fibre remains as a connective tissue that provides its connection with the external environment. During the ecdysis, exuvial space widens, apolysis is highly likely to occur in this process with freeing of the epidermis from the old exoskeleton. It is also thought that the intracuticular fibre located near the rupture point is contributed to the opening of the first rupture on the propeltidium. Altner \& Prillinger (1980) indicated for hemimetabolous insect that the development starts with the outgrowth of the dendritic outer segment together with the cuticular sheath and in the moulting process elongation of both structures brought about a strand that bridges the ecdysial space between the sensillum of old cuticle and the anlage of the new sensillum within epidermis. This strand is most probably same as the structure defined as intracuticular fibre in this study. They also emphasized that the cuticular sheath might be protecting the elongated dendrites from the enzymes in the exuvial space. The hard structures like tarsal claws on legs, cheliceral tip, and teeth not moulted literally but left incomplete pieces. Wharton (1981) also mentioned this process as changing of teeth size and shape with each moulting. In this case, teeth and tarsal claws will be small in size and this will cause systematic questioning because of dentition.

Punzo (1998) said that burrows are utilized for the digestion of food, oviposition, aestivation, ecdysis, and as places for protection during periods of inactivity. In this study, the burrows observed in the habitat and under laboratory conditions were circular and lateral lying position of preecdysial galeodid at equal height with of the burrows. During this quiescence stage, solifuge only twisted its opisthosoma in the burrow. It is thought that these twistings were effective in the formation of the circular burrow.

Ethics committee approval: Ethics committee approval is not required for this study.

Conflict of interest: The author declares that there is no conflict of interest. 

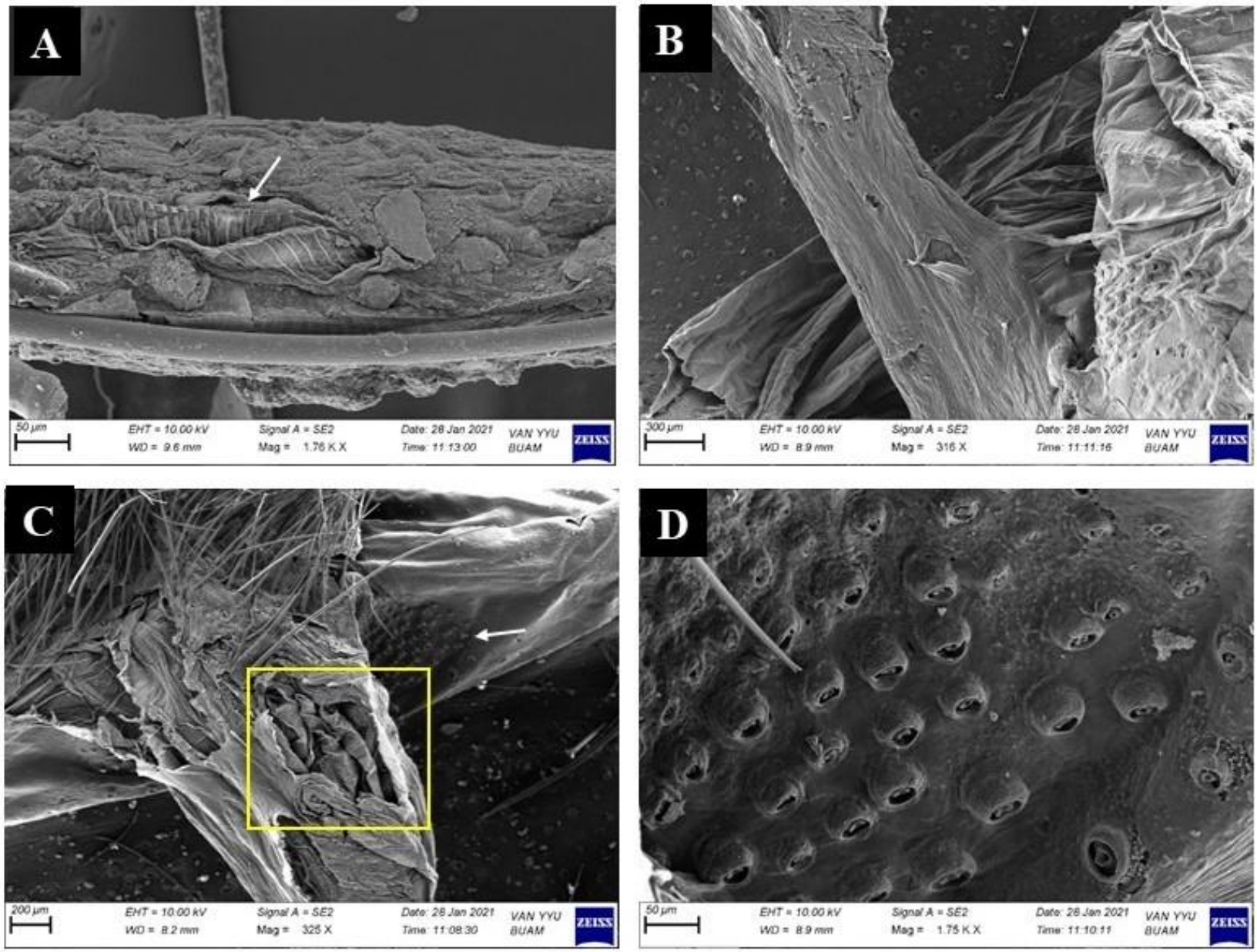

Figure 3. The intracuticular fibre connected to the propeltidial exuvium of Galeodes sp., dorsally (A-C), (Arrows show trachea in Fig. A and setal moulting area in Fig. C, and the square shows tracheae in Fig. C). Sockets of the moulting setae (D).
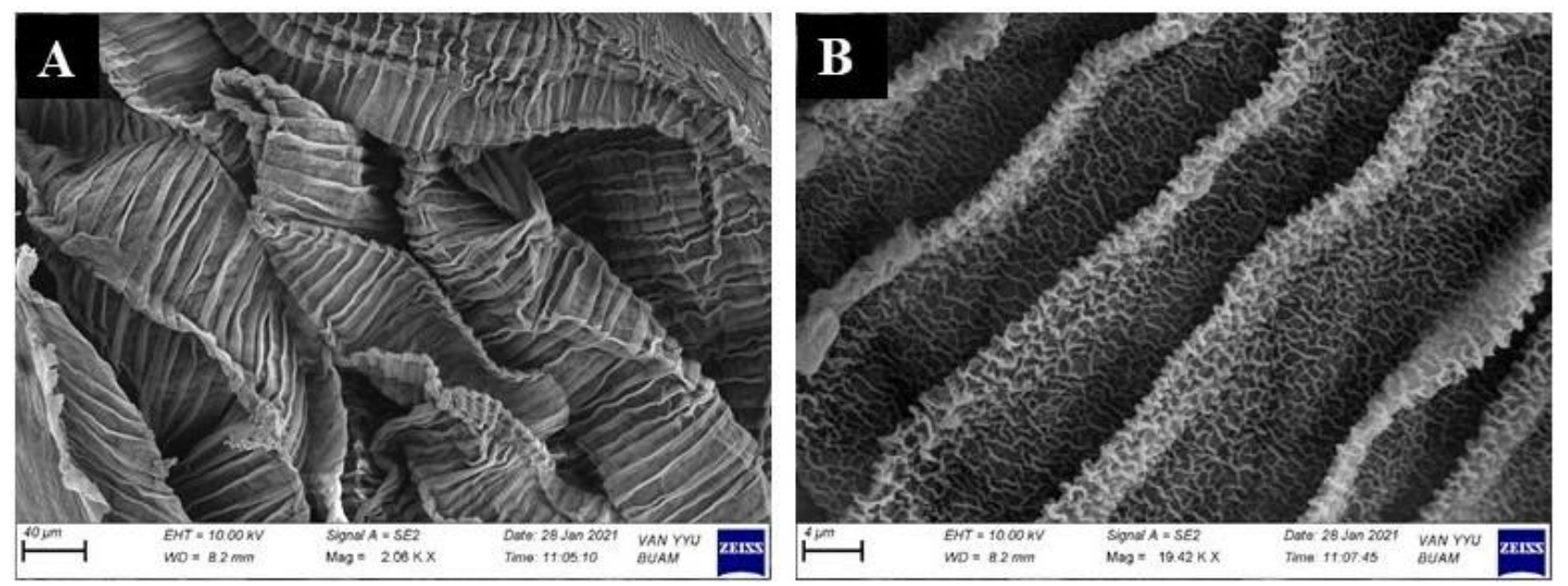

Figure 4. The transversal folds of tracheae in intracuticular fibres connected to exuviae of Galeodes sp. (A), Close-up to the transversal folds of tracheae (B).

\section{References}

Altner, H., \& Prillinger, L. (1980). Ultrastructure of invertebrate chemo-, thermo-, and hygroreceptors and its functional significance. International Review of Cytology, 67, 69-139. https://doi.org/10.1016/S0074-7696(08)62427-4

Erdek, M. (2019). Description of the new solifuge Gylippus (Paragylippus) hakkaricus sp. n. (Gylippidae, Solifugae). Zootaxa, 4695(6). https://doi.org/10.11646/zootaxa.4695.6.6

Harvey, M.S. (2003). Catalogue of the smaller arachnid orders of the world. Collingwood, Australi, CSIRO Publishing, 385 pp.
Haupt, J. (1982). Hair regeneration in a solfugid chemotactile sensillum during moulting (Arachnida: Solifugae). Wilhelm Roux's archives of developmental biology, 191(2), https://doi.org/10.1007/BF00848452

Muma, M.H. (1966). The life cycle of Eremobates durangonus (Arachnida: Solpugida). The Florida Entomologist, 49(4), 233-242. https://doi.org/10.2307/3493886

Punzo F. (1998). The Biology of camel-spiders (Arachnida, Solifugae). Kluwer Academic Publishers, Boston, MA. 1-297.

Wharton, R.A. (1981). Namibian (South Africa) Solifugae. Cimbebasia Memoir, 5, 3-87. 